Jelliffe, D. B., Bras, G., and Stuart, K. L. (1954). The clinical picture of veno-occlusive disease of the liver in Jamaican children. Annals of Tropical Medicine and Parasitology, 48, 386.

McLean, E. K. (1969). The early sinusoidal lesions in experimental veno-occlusive disease of the liver. British fournal of Experimental Pathology, 50, 223.

—, Bras, G., and György, P. (1964). Veno-occlusive lesions in livers of rats fed Crotalaria fulva. British fournal of Experimental Pathology, 45, 242.

Selzer, G., and Parker, R. G. F. (1951). Senecio poisoning exhibiting as Chiari's syndrome. American fournal of Pathology, 27, 885

Stuart, K. L., and Bras, G. (1957). Veno-occlusive disease of the liver. Quarterly fournal of Medicine, 26, 291.

Mohamed Al-Hasany and Abdul Salam Mohamed Department of Paediatrics, Children's Welfare Hospital, University of Baghdad: and Central Institute of Pathology, Baghdad, Iraq.

\section{Cutis Marmorata Telangiectatica Congenita or Congenital Generalized Phlebectasia}

Cutis marmorata telangiectatica congenita or congenital generalized phlebectasia is a rare disorder of the newborn characterized by prominence of the veins and capillaries of the skin, and other features. Despite the striking appearance of the condition the prognosis in the few patients so far reported has been good. The infant discussed in this paper had all the usual features, but in addition showed defective growth in the left arm, left leg, and left side of the trunk. These were the areas of the body in which the skin abnormality was most prominent.

\section{Case Report}

A full-term female infant was born at home in January 1969 , birthweight $2 \cdot 468 \mathrm{~kg}$. The delivery was uncomplicated but it was three minutes before respirations were established and regular. The infant's skin was very obviously abnormal, and she was therefore admitted to the Special Care Baby Unit at King's Mill Hospital the same day.

The 25-year-old mother was in good health and had two other children alive and well. The pregnancy had been uneventful. $\mathrm{Hb}$, blood pressure, and urine had been consistently normal, and the only drug she received was Ferrograd-Folic, one tablet daily from the 5th to the 8th month.

Examination. On admission to the hospital the baby's colour was good and respirations were normal. The skin, however, presented a striking appearance
(Fig. 1), and the most obvious feature was the prominence of veins over the legs, arms, and trunk. Many of the veins were dilated; others, however, appeared of normal calibre and together they produced a marble-like effect. The abnormality was most marked on the left side of the body, and in these areas the skin was extremely thin and translucent. The subcutaneous tissue appeared deficient, producing a 'skinned rabbit' effect, and it seemed as if it would have taken little pressure to cause the skin to tear. There were two small irregular-shaped ulcers of the left lower leg, and over the back of the hands and just above the knees were areas in which it appeared several veins had coalesced to form small venous 'lakes' or pools. Similar smaller areas were present elsewhere, and there were also scattered ecchymoses, particularly on the lower left leg; between the dilated veins, the venous pools, and the ecchymoses were areas of skin showing multiple telangiectases which could be obliterated by pressure. The palms, soles, and most of the head, face, and neck were normal, and the baby appeared otherwise healthy.

Progress. The infant remained alert and eager to feed. The two ulcerated areas on the left lower leg dried and showed signs of early healing. By the end of the first week the baby was gaining weight and there was improvement in her appearance. This seemed to be due to a general increase in thickness of the skin and subcutaneous tissue, so that the veins and capillaries were better covered and hence less easily visible. Some of the ecchymoses were gradually obliterated and the baby was discharged from hospital at the age of 3 weeks, weighing $2 \cdot 822 \mathrm{~kg}$.

In out-patients at the age of 8 weeks there was obvious further improvement, and areas of the skin which had shown the cutis marmorata effect were now normal. Other areas, however, which had been more translucent, were still abnormal, but the subcutaneous tissue was less obviously deficient.

The baby progressed satisfactorily, but by the age of 4 months it was apparent that the growth of the body was asymmetrical, and there was a $2.5 \mathrm{~cm}$. difference in the circumference of the left arm and the left leg compared with the right arm and the right leg. The left side of the trunk, the left pectoral, and the left shoulder region were also smaller than on the right side. The movements of the limbs were equal and the reflexes and sensations normal. $X$-rays of the underlying bones showed no abnormality. At the age of 12 months (Fig. 2) the improvement has continued, and the skin is very much less abnormal than at birth.

\section{Discussion}

The nomenclature of vascular abnormalities of the skin is complex and the condition under discussion has to be differentiated from genuine diffuse phlebectasia first described by Bockenheimer in 1907, and subsequently by Freund in 1936. The patients they described had a slowly progressive and painful lesion of veins of an extremity. The veins 


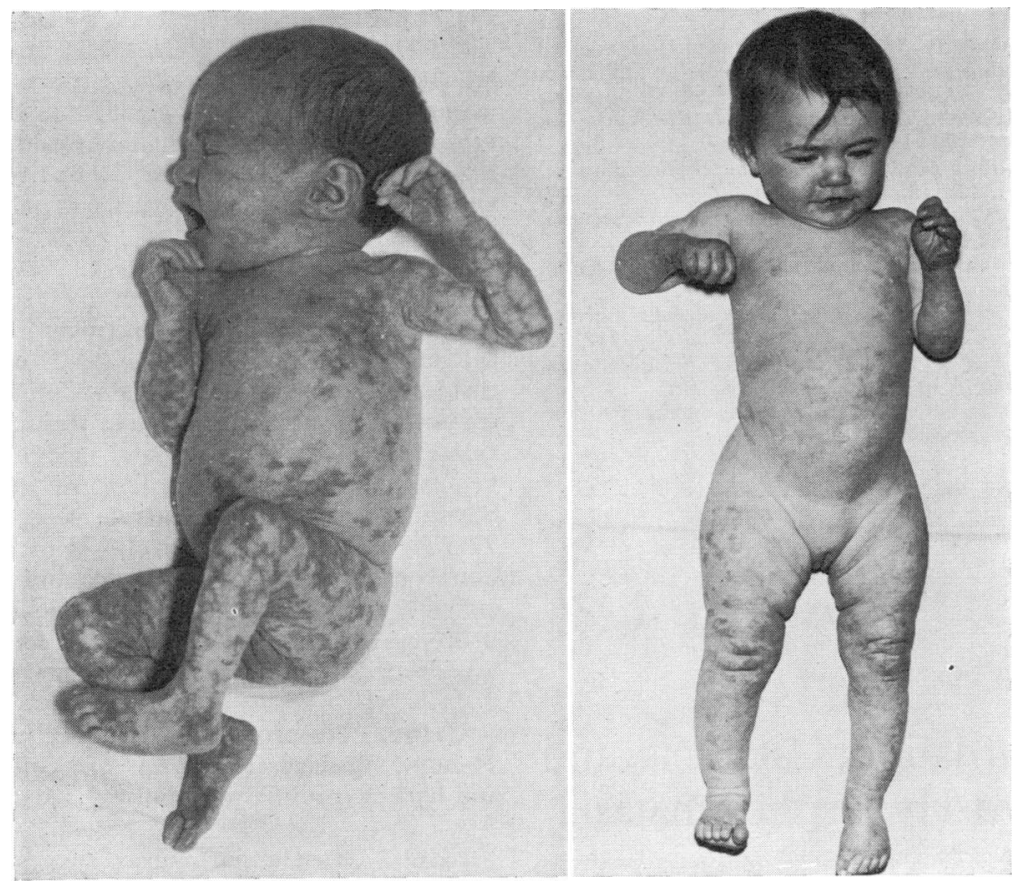

FIG. 1.-Patient aged seven days. FIG. 2.-Patient aged twelve months.

became enlarged, the overlying skin frequently atrophic and the dilated venous channels formed tumour-like prominences. The lesions developed spontaneously and usually occurred in childhood, suggesting to the authors the possibility of a congenital origin.

In 1922 Van Lorurizen and Van Giles-Van West described two patients with a widespread congenital and non-progressive abnormality of the skin which they named cutis marmorata telangiectatica congenita. Humphries (1952) reported a patient with similar abnormalities under the title of generalized congenital phlebectasia, and stressed the benign nature of the condition. The patient, a female negro infant, exhibited the characteristic marble skin effect due to the presence of dilated, easily observed superficial tissue. The patient described by Bedell and Allison (1964) had similar features, and they also commented on the apparent lack of subcutaneous tissue which was such a marked feature in our patient.

Mizrahi and Sachs reported a case in 1966 and included a report of a skin biopsy which showed dilated vessels throughout the cutis with occasional thin-walled empty sinusoids which could have been lymphatics or capillaries. There was oedema present in some of the perivascular spaces, and in view of these ill-defined changes they concluded that the diagnosis remained a clinical, and not a histological, one.

Ulceration of the skin was a feature in most of the patients reported including the infant described by Moyer in 1966. He reverted to naming the condition cutis marmorata telangiectatica congenita, and enumerated the five features of the disorder as initially suggested by Van Lorurizen. These are persistent cutis marmorata, phlebectasia, telangiectasia-like spider naevi, ulceration of the skin, and steady improvement from birth.

\section{Summary}

A case of cutis marmorata telangiectatic congenita, or congenital generalized phlebectasia is described in a full-term female infant.

This patient indicates the marked improvement that can be expected, but in addition she also had defective growth of the most severely affected areas, a complication not previously described.

We thank Miss M. A. Turner, S.R.N., S.C.M., N.N.E.B., Senior Sister, and the staff of the Special Care Baby Unit, King's Mill Hospital, Sutton-in-Ashfield, Notts. 


\section{REFERENCES}

Bedell, R. F., and Allison, J. R., Jr., (1964). Congenital generalized phlebectasia in a newborn. Archives of Dermatology, 90, 83.

Bockenheimer, P. (1907). Uber die genuine diffuse Phlebektasie der oberen Extremität. Festschrift G. E. von Rindfleisch, ed. by $M$. Borst, p. 311 . W. Engelmann, Liepzig.

Freund, E. (1936). Diffuse genuine phlebectasia: report of a case. Archives of Surgery, 33, 113.

Humphries, J. M. (1952). Generalized congenital phlebectasia. Fournal of Paediatrics, 40, 486.

Moyer, D. G. (1966). Cutis marmorata telangeictatica congenita. Archives of Dermatology, 93, 583.

Mizrahi, A. M., and Sachs, P. M. (1966). Generalized congenital phlebectasia. American fournal of Diseases of Children, 112, 72.

Van Giles-Van West (1922). Cutis marmorata telangeictatica. Nederlandsch Tijdschrift voor Geneeskunde, 66, 225.

Van Lorurizen, C., (1922). Cutis marmorata telangeictatica congenita. Acta Dermatovenero, 3, 209.

J. S. Fitzsimmons and M. Starks

Nottingham Children's Hospital, Chestnut Grove, Nottingham.

\section{Mental Retardation, Cataracts, and Unexplained Hyperphosphatasia}

We report a 4-year-old boy with a persistently raised serum alkaline phosphatase, $90 \%$ of which was of bone origin. There was no evidence of bone disease.

\section{Case History}

This boy was referred to the Department of Child Health of the Children's Hospital, Sheffield, for investigation of mental retardation associated with convulsions and bilateral cataracts at 4 years and 4 months of age. $\mathrm{He}$ was the first child of healthy, non-consanguineous parents. His mother had one fit in early childhood. There was a history of mild toxaemia, but not of rubella, during the pregnancy which terminated at 36 weeks' gestation. Birthweight was 1800 g., head circumference $39.7 \mathrm{~cm}$. Though covered with thick offensive liquor at birth the child's condition was satisfactory till the fourth day of life, when he had a cyanotic attack. He made a good recovery after a course of penicillin given for presumed inhalation pneumonia.

The first year of life was uneventful, though his milestones were delayed. At 20 months of age he had his first convulsion; the CSF was normal and there was no hypoglycaemia. Anticonvulsant therapy was started. At 28 months he was found to have bilateral cataracts. During the third year of life he had two further convulsions. The seizures have always been right-sided with loss of consciousness and transient hemiparesis. During his third seizure the blood glucose was $15 \mathrm{mg} . / 100 \mathrm{ml}$. The convulsions were becoming more frequent but with an increase in the dose of anticonvulsant they are now less severe, consisting of right-sided twitching, with no loss of consciousness or paresis.
Examination. Height $97.5 \mathrm{~cm}$., weight $15.4 \mathrm{~kg}$. Skull circumference $50 \mathrm{~cm}$. His intelligence, assessed by the educational psychologist, was recorded as low normal. Hearing was normal, but vision poor due to cataracts. The cardiovascular, respiratory, and neurological systems were normal. The liver was firm with a smooth surface; a sharp border was palpable $3 \mathrm{~cm}$. below the costal margin.

Blood. Hb, WBC, plasma urea, sodium, potassium, bicarbonate, and amino nitrogen, serum proteins, calcium, inorganic phosphates, bilirubin, thymol turbidity, thymol flocculation, glutamic oxaloacetic transaminase, glutamic pyruvic transaminase, 5 nucleotidase, galactose-1-phosphate uridyl transferase, and bromsulphalein excretion were normal. Alkaline phosphatase (on three separate samples) 376,88 , and $77 \mathrm{KA}$ units $/ \mathrm{ml}$., respectively. Further analyses were done on the third sample. Alkaline phosphatase isoenzyme electrophoresis showed one band (Rf $0.56 \pm$ 0.02 ). After incubation at $56^{\circ} \mathrm{C}$. for 15 minutes $90 \%$ was destroyed, indicating osseous origin.

Urine. No protein or reducing substances present. 24-hour urinary excretion of calcium, creatinine, and hydroxyproline were normal.

EEG. Gross abnormalities suggestive of grand mal epilepsy.

X-ray. Full skeletal survey showed no radiological abnormality.

\section{Discussion}

Normal adult serum contains predominantly alkaline phosphatase of liver origin, with a small but variable quantity of intestinal enzyme and little or no bone enzyme. In childhood and infancy there is in addition a bone iso-enzyme. Views differ as to the normal value for serum alkaline phosphatase in children; the range given by Gray (1965) was 15-20 KA units $/ \mathrm{ml}$, and that by King (1951) 10-30 KA units $/ \mathrm{ml}$. for children aged 1-3 years. Increases in the serum alkaline phosphatase may be secondary to bone or liver disease. The commoner bone diseases causing such increases are rickets, healing fractures including the battered baby syndrome, hyperparathyroidism, neoplasia with bone involvement, infantile cortical hyperostosis (Caffey's disease), and congenital hyperphosphatasia (Caffey, 1961).

The increase in the alkaline phosphatase level in this patient was chiefly attributable to bone isoenzyme. In spite of this, a full radiological skeletal survey showed no bony lesions. Though it is appreciated that enzyme changes may appear before bone change becomes evident, one would certainly expect some bone change and alteration in the 